\title{
Akram Aylisli's Lonely Battle for Reconciliation
}

$\mathrm{O}$ n February 10, 2013, a crowd gathered in Azerbaijan to burn books. Book burning may seem like an activity out of another era or a metaphor for past censorship and dictatorship rather than something that really happens today. But a video of the event shows a gathering of a couple dozen people, mostly middle-aged and older, many wearing suits and ties. ${ }^{1}$ With little apparent enthusiasm they methodically tear up old hardcovers and throw the pages onto a pile. A balding man in jeans and a leather jacket pours some fuel out of a reused vegetable oil bottle onto the books and then lights it in several places with a cigarette lighter. The crowd watches stoically as the fire rages brightly and eventually dies out, leaving the books in ashes.

The target of this sad episode was Akram Aylisli and his novella Stone Dreams, which had just been published in the Russian literary journal Druzhba narodov (Friendship of Peoples). The books being burned were mostly old editions of Aylisli's other works - there was no copy of Stone Dreams in the pyre because it hadn't even been published in Azerbaijan.

This particular book-burning was in Ganja, Azerbaijan's second largest city, but similar events took place in the capital, Baku, and other cities around Azerbaijan. And the reception of Stone Dreams was not limited to book burning. One politician offered a reward of more than \$10,000 to anyone who cut off Aylisli's ear and brought it to him; others demanded that he undergo a blood test that would determine if he was truly Azerbaijani. President Ilham Aliev, citing Aylisli’s "deliberate distortion of the history of Azerbaijan by his entirely slanderous work," issued a decree formally stripping Aylisli of his title as "People's Writer" and revoking the

1 “Azerbaijani Writer's Books Burned over His Controversial Novel," Radio Liberty's website, February 11, 2013. https://www.rferl.org/a/azerbaijani-writer-books-burned-akramaylisli/24898784.html. 
special pension that he had received as a distinguished artist. ${ }^{2}$ His works were removed from school curricula and his plays were pulled from theaters.

Aylisli's "crime" was that he wrote about his own country's crimes against Armenians and not the other way around. ${ }^{3}$ Over more than a century of bloodletting, there have been plenty of atrocities on both sides. That Aylisli chose to focus on the blood shed by his own people makes him almost unique among Azerbaijanis (and, for that matter, Armenians).

Aylisli had been a leading Azerbaijan literary figure since the 1960s, one who managed the rare feat of enjoying both official and popular support in both the Soviet Union and in independent Azerbaijan. His works were in school curricula, and he served as a member of Azerbaijan's parliament from 2005 until 2010.

Aylisli had previously spoken out against anti-Armenian hatred in Azerbaijan, most notably in a 1989 debate published in Druzhba narodov, a time when many more intellectuals on both sides were instead whipping up nationalist hysteria against the other. ${ }^{4}$ But Stone Dreams went much farther in grappling with the conflict.

The novella alternates between two narratives. The first is the history of Aylis, Aylisli's hometown in Nakhchivan, a landlocked exclave bordering Armenia, Iran, and Turkey. It was here that Armenians were massacred by Ottoman troops, who had invaded to support local Azeris in a fight for control with Armenians over the region, in 1919. The massacre-a relatively little-known episode in the Armenian genocide, in which up to 1.5 million Armenians were killed-wiped out what had been a vibrant Armenian community in Aylis. Its Armenian churches, once

2 Rasporiazhenie Prezidenta Azerbaidzhanskoi Respubliki o lishenii Akrama Ailisli (Akrama Nadzhaf oglu Naibova) personal'noi pensii Prezidenta Azerbaidzhanskoi Respubliki [Azerbaijani President Ilham Aliev's decree on the cancellation of Akram Aylisli’s personal "Presidental Pension"], President Ilham Aliev's official website, February7, 2013, https://ru.president.az/articles/7230.

3 Some, including Aylisli himself, have suggested that it wasn't actually Stone Dreams that got Aylisli in trouble with the authorities, but the next installment in the trilogy, A Fantastical Traffic Jam. That novella portrays a dictator who resembles Heydar Aliev, the former president and founding father of modern Azerbaijan; it was published in Baku in a small Russianlanguage edition in 2011.

4 The debate (or, more precisely, that part of a very long public discussion dedicated to the problems of nationalism) began with a letter by Aylisli and a reply to it by then-editor-in-chief of Druzhba narodov, Sergei Baruzdin, both published in the March 1989 issue of the journal. Later this debate continued with a collective letter of the Azerbaijani Writers Union that appeared in the October 1989 issue. Akram Aylisli, "Poka v dome budet sushchestvovat' liubov' . . : pis'mo S. A. Baruzdinu" [As long as love exists at home ...: Letter to S. A. Baruzdin], Druzhba narodov 3 (1989): 170-171; Sergei Baruzdin, "Emotsii i fakty" [Emotions and facts], ibid.: 171-174; General Committee of the Azerbaijani Writers Union, "V redaktsiiu zhurnala 'Druzhba narodov', glavnomu redaktoru S. A. Baruzdinu" [To the editorial desk of Druzhba narodov, Editorin-Chief S. A. Baruzdin], Druzhba narodov 10 (1989): 233-235. 
famed around the region, were abandoned, and Armenians' homes were occupied by Azeris, often the ones who had abetted the Turkish slaughter.

The second narrative concerns the pogroms that Azerbaijanis carried out against Armenians in Baku and other cities in Azerbaijan between 1988 and 1990. As the Soviet Union was falling apart, interethnic tensions rose in many peripheral parts of the empire, and some of the worst tension was between Armenians and Azerbaijanis. This tension would eventually lead to a war between the two sides; among the most notorious episodes was a series of organized slaughters of Armenian residents of Azerbaijani cities, most notoriously in Sumgait, carried out by bands of Azerbaijani men. The pogroms themselves killed some unknown dozens and forced virtually all Armenians who had been living in Azerbaijanincluding 250,000 in Baku alone-to flee. "If a single candle were lit for every Armenian killed violently, the radiance of those candles would be brighter than the light of the moon," says one of Aylisli's characters in Stone Dreams.

To a generous reader of Stone Dreams, the dominant impression of Azerbaijan is of the humanity and decency of the main characters of the novel, people who respect their Armenian neighbors and lament the cycle of hatred that has swallowed their country. But many of its readers were not generous. Some in Azerbaijan accused Aylisli of trying to mimic the Turkish novelist Orhan Pamuk, who won the Nobel Prize in Literature and had been the subject of controversy in Turkey because of his frank acknowledgement of the Armenian genocide. A group of prominent academics nominated Aylisli for the Nobel Peace Prize in 2014, crediting him as "the first Turkic author to write a novel about the Armenian genocide" and praising his "amazing courage in the cause of overcoming hostility between the peoples of Azerbaijan and Armenia."5

Aylisli anticipated the accusations that were made against him in his text. The wife of Sadai Sadygly, the hero of Stone Dreams, asks her husband about his sympathy toward Armenians:

Yes, I was in Aylis, and I know the Turks dealt brutally and cruelly with innocent people there. But you've also been in those places from which Armenians drove out thousands of unfortunate Azerbaijanis. Have you thought even once about how it is for those unfortunate people, those Azerbaijanis, homeless now and living without the slightest hope for the future? Do our Azerbaijani instigators, the ones who stirred up this bloody

5 The Nobel Peace Prize 2014 nomination, unofficial website of Aylisli, http://akramaylisli. info/english/nomination/. 
trouble, really think about them, the Azerbaijanis whom the unfortunate Armenians themselves now curse? I mean both the Karabakh Armenians and the local Baku Armenians who don't care about us because, according to their thinking, we're also Turks? If the Turks slaughtered your people, go ahead, fight it out with them, why are we Azerbaijanis even involved? In what way are those Armenian screamers better than our homegrown ones? Why don't you think about that, my dear?

Elsewhere in the novella another character, seemingly channeling Aylisli, articulates Sadai's attitude on this question: "What today's Armenians are like is beside the point- the point is, what we're like now."

These sorts of sentiments are vanishingly rare today in the Caucasus, where a quarter century of nationalist propaganda by both Armenians and Azerbaijanis has fuelled a deep hatred on both sides. But the history of Armenian and Azeri cohabitation is much longer than their history of enmity. For centuries Armenians and Azeris peacefully intermixed throughout the South Caucasus, the region south of the Caucasus Mountains (which extends along what is today Russia's southern border), northeast of Turkey and northwest of Iran. The Caucasus is one of the most ethnically diverse regions in the world, and Armenians and Azerbaijanis are just two parts of an immensely complex ethnic patchwork. Azeris (who now are divided between the Republic of Azerbaijan, founded in 1918, and the Iranian province of Azerbaijan) are mostly Shi' a Muslims and speak a Turkic language closely related to modern Turkish. Armenians belong to the Nestorian branch of Orthodox Christianity and speak a language that is its own branch of Indo-European. Despite these basic differences, centuries of shared history under Ottoman, Safavid, Tsarist, and Soviet rule have brought them together. Much Armenian and Azerbaijani traditional music and many of their dances are very similar. Armenian and Azeri literatures are similarly informed by a shared Persianate and subsequently, Soviet ethos. The regular quarrels that the two sides now have over the provenance of their favorite foods-like stuffed grape leaves, thin lavash bread, and meatballs - only serve to demonstrate how similar their cultures are.

The comity that Armenians and Azeris had with one another began to disappear in the late nineteenth and early twentieth centuries as ideas of nationalism - a European import transmitted via Russia and Turkey-took root among the region's intellectuals. As the Russian Empire declined and control from the center weakened, disorder spread across the Caucasus. 
The first major clashes between Armenians and Azeris took place in 1905 in Baku and then spread to other parts of the South Caucasus. The fighting began as labor disputes but took on an ethnic cast. The clashes would be reprised in the chaotic years following the 1917 Russian Revolution and collapse of the Russian Empire. This time they were exacerbated by the invasion of the Ottoman armed forces, who sought to take advantage of the chaos in the former Russian Empire and took the side of Azeris against Armenians.

Eventually the Russians - this time reorganized as the Soviet Unionreconquered the Caucasus and managed to tamp down the violence. Under the USSR the South Caucasus was divided up into three Soviet Socialist Republics-Armenia, Azerbaijan, and Georgia. The Soviets were thus forced to decide which land to allocate to Armenia and which to Azerbaijan. The solution was necessarily imperfect, and Soviet Azerbaijan was a particularly curious creation. It included Nakhchivan, an exclave roughly the size of Delaware, separated from the rest of Azerbaijan by a swath of Armenian territory. Another territory that ended up in Azerbaijan was Nagorno-Karabakh, an enclave slightly smaller than Nakhchivan, which due to its Armenian majority population was given a special status (it was an "autonomous oblast" in Soviet terminology). This awkward division appears to have been motivated by a good-faith effort to assign, as best as possible, the region's manifold nationalities into unitary boxes. But both Armenians and Azerbaijanis would later complain, along with many other Soviet peoples who suffered a similar fate, that their forced cartographies were instead deliberate time bombs set by the Soviets to explode in case of the Soviet Union's disintegration.

For most of its existence, the Soviet Union managed to keep a lid on the ethnic tension between Armenians and Azerbaijanis that had plagued the early twentieth century. Baku was one of the most cosmopolitan centers in the entire USSR. The chess grandmaster Garry Kasparov, who grew up in Baku with a Jewish father and Armenian mother, described his nationality as "Bakuvian." Interethnic marriages were common with Georgians as well as Armenians. Baku Armenians commonly spoke Russian as a first language rather than Armenian.

Still, Nakhchivan and Nagorno-Karabakh underwent significant demographic shifts as a result of being assigned to Azerbaijan. In Nakhchivan, the Armenian population - which had been roughly 40 percent before the Soviet takeover-dropped to only 11 percent by 1926 and barely 1 percent by 1979 . In Karabakh, the proportion of the Azerbaijani population grew as well, but Armenians still accounted for about three-quarters of the population at the end of the Soviet era. 
During the second half of the twentieth century, Armenians' consciousness about the genocide-which had been largely repressed in the decades immediately following - grew, both in the Armenian diaspora and in Soviet Armenia. A mass demonstration in Yerevan in 1965 marked the genocide's fiftieth anniversary. The sense of loss that Armenians had experienced as a nation grew to encompass other lost lands, including Nagorno-Karabakh. As nationalist movements blossomed across the Soviet Union in the 1980s, one of the most powerful was the Karabakh Movement among Armenians, which sought for Nagorno-Karabakh to be removed from Azerbaijan and united with Armenia.

This movement snowballed and eventually led to war between Armenia and Azerbaijan, which ended in a ceasefire in 1994 after an estimated 30,000 were killed. Nagorno-Karabakh and some surrounding territories of Azerbaijan came under the control of Armenian forces, and the populations on both sides were ethnically cleansed. The legacy of the war has had a profound impact on Azerbaijan today. Just as Armenians were forced to flee their homes in Azerbaijan, over 600,000 Azerbaijanis who had been living in areas now controlled by Armenia also were forced out. ${ }^{6}$

The sense of resentment over the war has been nurtured and manipulated by the Azerbaijani government, which has developed into one of the most repressive states on the planet. In the widely respected Polity IV rankings compiled by political scientists, only 10 countries in 2017 were more autocratic than Azerbaijan, which ranked alongside Iran, China, and Cuba. ${ }^{7}$

Hatred of Armenians is virtually state policy in today's Azerbaijan. In practice, no one with an Armenian name (easy to spot, as they end in -yan or -ian, as with Alikhanyan, Kocharyan, and Petrosyan in this volume) is allowed into the country; if they arrive at the airport, even if they are from a country for which visas to Azerbaijan aren't required, they are turned back. Police have even investigated Azerbaijanis who vote for Armenia in the Eurovision Song Contest.

At the same time, Azerbaijan also has become relatively wealthy, earning billions from its oil and gas reserves on the Caspian Sea. It has spent heavily on flamboyant architecture, attempting to turn Baku into a sort of post-Soviet Dubai, as well as on its military, with which it regularly threatens to take back Nagorno-Karabakh by force.

6 Azerbaijan Factsheet, UN Azerbaijan, May 1, 2018, https://unazerbaijan.org/wp-content/ uploads/2018/05/Factsheet_Aze_1-May-2018-v1.pdf.

7 Polity IV Individual Country Regime Trends, 1946-2013, website of Center for Systemic Peace, http://www.systemicpeace.org/polity/polity4x.htm. 
In Armenia, meanwhile, victory in Nagorno-Karabakh has turned out to be a Pyrrhic one. Its borders with Azerbaijan and Turkey (a close ally of Azerbaijan) are closed, stifling its economy. The constant military threat from Azerbaijan has forced it into an alliance with Russia, which has a military base in Armenia and gives the country military aid to help make up for Azerbaijan's substantial military spending advantage. (To add to the humiliation, though, Moscow also sells Azerbaijan the large majority of that country's weapons.) As in Azerbaijan, hatred of the other side has only grown since the war.

International mediators (led by the US, Russia, and France) have been trying to hammer out a peace deal to resolve the Nagorno-Karabakh conflict, but diplomatic talks have stalled and become more focused on preventing another war than on a lasting peace. On both sides, rising nationalism has made it virtually impossible for the respective leaders to make the kinds of compromises that would be necessary for a real peace deal.

One of the many low points in this sad history is the story of Ramil Safarov. On the evening of February 18, 2004, Safarov killed Gurgen Margarian with sixteen ax blows to the head while the latter was asleep in his bed. The two men were participating in an English-language training seminar in Budapest organized by NATO. Both were young lieutenants in their respective armed forces: Safarov for Azerbaijan, Margarian for Armenia. During his trial in Hungary, Safarov's lawyers explained that their client had suffered from post-traumatic stress as a result of his family's expulsion from their home during the war between Armenia and Azerbaijan. Safarov's home region of Jabrayil, adjacent to Nagorno-Karabakh, was occupied by Armenian forces and the entire ethnic Azerbaijani population, including Safarov's family, was forced to flee. The Hungarian judge was not moved by that justification and in 2006 gave Safarov a life sentence in prison, with no right to appeal for thirty years.

In 2012, however, shortly after a state visit by Hungarian Prime Minister Viktor Orban to Azerbaijan, Hungary extradited Safarov back to his home country. He was immediately pardoned and set free, promoted to major, and given eight years of back pay and a free apartment. "It is very touching to see this son of the homeland, [who] had been thrown in jail after he defended his country's honor and dignity of the people," said Novruz Mammadov, Aliev's top foreign policy adviser, upon Safarov's release. ${ }^{8}$

8 "Agreement during Hungarian Premier's Visit Decisive in Ramil Safarov's Issue," News.az, September 1, 2012, https://news.az/articles/67397/print. 
The pardon was widely condemned internationally: the US Department of State and White House, French and Russian foreign ministries, the European Union foreign affairs representative, and United Nations secretary general all issued statements criticizing the move. In Azerbaijan itself, however, critical voices were scarce. And this was what prompted Aylisli to release Stone Dreams. "When I saw the crazy reaction and the artificial fueling of hatred between Armenians and Azerbaijanis, which went beyond any borders, I decided to publish my novel," he said in a 2013 interview. ${ }^{9}$

Even after the initial furor over the publication of Stone Dreams died down, Aylisli has continued to be the subject of an intimidation campaign; in 2016 he was on his way to a literary conference in Venice when he was stopped at the airport and accused of attacking a border guard. For the most part, though, he has kept a low profile. "Let some in my motherland think I'm not a writer: so be it," he writes in the afterword to this edition. "I don't need honor or glory in a country where they burn books and a killer with an ax is elevated to the rank of hero."

Meanwhile, the tension between the two sides has continued to grow. April 2016 saw the heaviest fighting since the 1994 ceasefire, with over 200 killed. And the inclination to take responsibility for crimes committed by one's own side is vanishing. Azerbaijan's government has begun to embrace a conspiracy theory that the pogroms in Sumgait, Baku, and elsewhere were in fact orchestrated by Armenians as a provocation. Armenians have done something comparable with the most notorious war crime on their side, a massacre of over 400 Azerbaijani civilians in the NagornoKarabakh village of Khojaly; Armenian politicians have frequently either denied that the massacre happened or have claimed that Azerbaijanis themselves carried it out.

Aylisli said in interviews after the release of Stone Dreams that he hoped Armenian writers would write about the crimes committed on their side of the conflict. "This novel is a kind of message to Armenians living in Karabakh," he said in one interview. ${ }^{10}$

9 Shahin Abbasov, "Azerbaijan: Writer Buckling under Strain of Literary Controversy," eurasianet, February 14, 2013, https://eurasianet.org/s/azerbaijan-writer-buckling-under-strain-of-literary-controversy.

10 Daisy Sindelar, "Azeri Author Sends Unpopular Message to Armenians: 'We Can Live Together," Radio Liberty's website, February 1, 2013, https://www.rferl.org/a/armeniaazerbaijan-stone-dreams-akram-aylisli/24890815.html. 
xvi | Joshua Kucera

Don't think that we've forgotten all the bad things we've done to you. We accept that. You have also done bad things to us. It's the job of Armenian writers to write about those bad things, about the Khojaly massacre. ... Because it's not possible for any people to commit such cruelties and not write about it. Don't politicize these things. If Armenians continue to live in the Karabakh region of Azerbaijan, we have to live side by side. This novel is a message to them. Don't be afraid. It's not the end. We can live together. $^{11}$

But in a development that was as depressing as it was predictable, the release of Stone Dreams had an entirely different impact in Armenia. Armenians loved the book: within four years of its publication, no fewer than five translations of the work into Armenian-none authorized by Aylisli-were produced. ${ }^{12}$ In 2014, Stone Dreams became one of two bestsellers of the year in Armenia. ${ }^{13}$

Armenians loved Stone Dreams because it "proved" that Azerbaijanis had been in the wrong. Aylisli's novella was cynically used by nationalist Armenians as evidence that it was Azerbaijanis who had more to apologize for, and his persecution was gleefully portrayed as yet more evidence of Armenians' superiority. Aylisli's call for Armenians to examine their own crimes against Azerbaijanis was ignored; Armenia is no more ready to examine its guilt than is Azerbaijan.

"At this point I don't see any Armenian writer who would take the risks that Akram Aylisli did," said Levon Javakhian, the Armenian writer who had perhaps come closest. He had written a short story, "Kirve" [Godfather], that expressed sympathy for Azerbaijanis, and he was criticized (and, he says, surveilled by the state) for it. "We don't have writers as brave as he is. They don't have the courage to write the kind of novel that Aylisli did, but just something as modest as my story 'Kirve." 14 Javakhian also noted, "For me, there is an

11 Ibid.

12 Alisa Gevogyan, "Facts Distorted in Azeri Author's Book: Argam Ayvazyan," website of Public Radio of Armenia, May 31, 2016, http://www.armradio.am/en/2016/05/31/factsdistorted-in-azeri-authors-book-argam-ayvazyan/.

13 Alisa Gevogyan, "Azerbaijani Writer Akram Aylisli's 'Stone Dreams' [is] One of the Bestsellers in Armenia," website of Public Radio of Armenia, February 21, 2014, http:// www.armradio.am/en/2014/02/21/azerbaijani-writer-akram-aylislis-stone-dreams-oneof-the-bestsellers-in-armenia/.

14 Mikail Mamedov, "The Stone Dreams Scandal: the Nagorny Karabakh Conflict and Armenian-Azerbaijani Relations in Contemporary Literature," Caucasus Survey 2, no. 1-2 (2014): 42-59. 
Azerbaijan of Ramil Safarov and an Azerbaijan of Akram Aylisli. Aylisli's novel elevated Azerbaijan, and didn't let it be stereotyped as a criminal with an axe."15

Aylisli has suffered greatly for his courageous stance; "tragedy" and "martyrdom" do not seem hyperbolic descriptions of what has happened to him. What risks getting lost in the political controversy, however, is that Aylisli is an excellent writer, well deserving of the accolades he once received in Azerbaijan. One can only hope that the political intrigue and historical disputes surrounding these novellas will attract readers who, then, are pleasantly surprised to find that his novels are also genuine works of art. This edition is a welcome introduction for an English-language audience to this great humanist and remarkable writer.

Joshua Kucera

15 Emil Sanamyan, "Acknowledgement and Praise: Armenian Reactions to Akram Aylisli's Novel Stone Dreams," Caucasus Survey 2, no. 1-2 (2014): 60-63. 